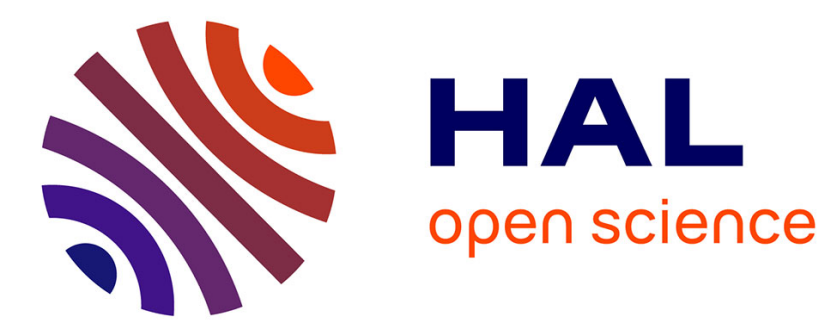

\title{
International Database on Human Capital Quality
}

Nadir Altinok, Hatidje Murseli

\section{To cite this version:}

Nadir Altinok, Hatidje Murseli. International Database on Human Capital Quality. 2006, 12 p. halshs-00097099

\section{HAL Id: halshs-00097099 \\ https://shs.hal.science/halshs-00097099}

Submitted on 21 Sep 2006

HAL is a multi-disciplinary open access archive for the deposit and dissemination of scientific research documents, whether they are published or not. The documents may come from teaching and research institutions in France or abroad, or from public or private research centers.
L'archive ouverte pluridisciplinaire HAL, est destinée au dépôt et à la diffusion de documents scientifiques de niveau recherche, publiés ou non, émanant des établissements d'enseignement et de recherche français ou étrangers, des laboratoires publics ou privés. 


\title{
International Database on Human Capital Quality
}

\author{
Nadir ALTINOK and Hatidje MURSELI ${ }^{\mathrm{a}^{*}}$ \\ ${ }^{\text {a }}$ IREDU (Institute for Research in the Sociology and Economics of Education) and CNRS (French National \\ Center for Scientific Research), University of Bourgogne, France.
}

\section{Working Paper IREDU - September 2006}

\begin{abstract}
In this research work, we have used a methodology which enables us to obtain qualitative indicators of human capital (QIHC) for 105 countries. This methodology relies on the potential to reconsider survey results comparatively by analysing the results of countries which took part in at least two different surveys. This allowed us to build indicators of comparable data concerning the quality of human capital in numerous countries and between 1964-2005: our results represent a valuable comparison to what has been done so far.
\end{abstract}

Keywords: Macroeconomic Data; Education Quality; Human Capital.

J.E.L. Classification: C82; I2.

\footnotetext{
* Corresponding author. Nadir ALTINOK - IREDU (Institute for Research in the Sociology and Economics of Education), UMR 5192, CNRS/Université de Bourgogne, Pôle AAFE - Esplanade Erasme - B.P. 26513, F 21065 Dijon Cedex (France). Fax. 00 (0)3 803954 79. E-mail : nadir.altinok@u-bourgogne.fr
} 


\section{Introduction}

Many studies have tried to estimate the extent to which education strengthens economic growth, and other studies have tried to check for the existence or not of an education production function. However, most of these studies tend to neglect the quality of education. This paper aims to provide better information about education quality. We have used a methodology which enables us to obtain qualitative indicators of human capital (QIHC) for approximately 105 countries. Hanushek and Kimko (2000) designed international data on student learning achievement results for a 70-country sample. Lee and Barro (2001) researched determinants of education quality in a panel database which includes education input and output measurements for a large number of countries. Hanushek and Kimko (2000) combined available test results in mathematics and science as a single score for each country. In comparison, Lee and Barro (2001) took into account results in mathematics, science and reading for children of different ages from 1964 to 1991.

Following a different methodology than that used by these authors, we have compiled two databases relative to education quality: the first is a cross-country database for approximately 105 countries and for the most recent year (database 1). The second is a panel dataset concerning the period between 1964 and 2005, which gathers all international surveys on children's achievement (database 2). This allowed us to obtain respectively 267 and 793 observations from database 1 and database 2 . The main difference between our work and that of Lee and Barro (2001), or that of Hanushek and Kimko (2000), is that we have based our research on a larger number of countries (most of them with low or intermediate income levels) whereas previous studies are often centered on high income countries. 


\section{Data}

Our data re-adjustment is based on eight international surveys on children's learning achievement (see Table 1).

\section{Methodology}

As there are eight international surveys analysing children's learning achievement, our study has tried to gather those surveys on a common scale in order to allow an international comparison of children's learning achievement across countries. We will fist present the methodology employed to obtain the cross-country database, followed by the panel database.

First, we selected countries which participated in at least two different surveys so as to establish a comparison between the surveys. The IEA surveys were chosen as reference surveys as they cover most of the countries and as the economic levels of participating countries are the most heterogeneous. We will present the general methodology as applied to mathematics. Note that we only used tests dated after 1995, because we wanted to obtain qualitative indicators for the most recent year. Therefore, to include as many countries as possible, we had to use several IEA surveys and not only the TIMSS 2003 survey. In order to assure a better comparison with the other surveys, we decided to use only data from grade 8 . We have therefore used three surveys in IEA mathematics (TIMSS1995, TIMSS1999, and TIMSS2003).

All the surveys were then adjusted to a 0-100 scale, with 100 as the highest possible score.

$\left(x_{i j}^{\bar{k}}\right)_{\text {adjusted }}=\frac{x_{\bar{i} j}^{\bar{k}}}{\max \left(x_{\bar{i} j}^{\bar{k}}\right)} \times 100$

Where $\left(x_{i j}^{\bar{k}}\right)_{\text {adjusted }}$ represent the adjusted results of survey $i$ for country $j$ in subject $k$. 
Note that index $i$ includes seven groups of surveys (SACMEQ, MLA, PASEC, LABORATORIO, PISA, TIMSS, PIRLS). Index $j$ includes all the countries participating in the different surveys. Index $k$ refers to the subject measured (mathematics, science, reading). Equation (1) therefore shows that the adjusted result $\left(x_{i j}^{\bar{k}}\right)_{\text {adjusted }}$ is obtained by dividing each result of the $i$ initial survey $x_{\bar{i} j}^{\bar{k}}$ by the maximum value of this survey $\max \left(x_{\bar{i} j}^{\bar{k}}\right)$, multiplied by 100 .

Note that we did not adjust survey variance because we allowed for a possible difference in variance between surveys. While Hanushek and Kimko (2000) adjusted surveys in order to have a mean of 50 and pondered them by a (normalized) standard error, Lee and Barro (2001) preserved absolute means, without pondering tests with any variance indicator. In our methodology, we were faced with two options: if we chose a standardisation of surveys by variance indicators, we would suppose that all surveys between 1964 and 2005 had the same mean and the same variance ; on the contrary, if we did not standardise tests, we would suppose that mean and variance of tests can vary over time. We chose the second hypothesis because the number and the nature of the countries which participated in the tests are very different among tests. It will be noted that, despite this absence of standardization by variance of tests, we nonetheless have comparable results, due to the methodology of matching with “doubloon countries".

Starting from the TIMSS indexes, we tried to track countries which had participated in the TIMSS and at least one other survey. It will be noted that all the surveys include countries which participated in the TIMSS and at least one other survey. (Except for the PASEC survey which does not include the countries of the TIMSS survey ${ }^{\dagger}$.)

\footnotetext{
$\dagger$ As for the re-adjustment of the PASEC survey to the referee survey, we have used the re-adjusted MLAsurvey.
} 
We then proceeded to a matching based on the means of those countries which participated in at least two surveys (called "doubloons"); each survey was re-adjusted according to how closely it fitted with the IEA survey which was taken as a reference.

$$
\bar{x}_{\tilde{i}, \text { doubloons }_{n}}^{\tilde{k}}=\frac{x_{\tilde{i}, \text { doubloons }_{1}}^{\tilde{k}}+x_{\tilde{i}, \text { doubloons }_{2}}^{\tilde{k}}+\ldots+x_{\tilde{i}, \text { doubloons }_{n}}^{\tilde{k}}}{n}=\frac{\sum_{i=1}^{n} x_{\tilde{i}, \text { doubloons }_{n}}^{\tilde{k}}}{n}
$$

Equation (2) records the operation used as to obtain the mean of the doubloons for each survey, which is noted $\bar{x}_{\tilde{i}, \text { doubloons }_{n}}^{\tilde{k}}$.

This was accomplished by calculating the mean of the results of the "doubloon countries", namely those which participated in both the IEA reference survey and the survey we want to adjust.

$\bar{x}_{\text {IEA,Country }}^{\tilde{k}}=\frac{x_{\text {IEA,Country }}^{\tilde{k}}+x_{\text {IEA,Country }}^{\tilde{k}}+\ldots+x_{\text {IEA,Country }}^{\tilde{k}}}{n}=\frac{\sum_{i=1}^{n} x_{\text {IEA,Country }}^{\tilde{k}}}{n}$

Equation (3) highlights the same operation as that performed on the IEA reference survey. We calculated the mean of the results for the "doubloon countries" of the IEA survey. In the next step, we calculated the transfer index from survey $i$ to the adjusted survey according to the IEA reference survey. This calculation was made by dividing the mean of the reference survey $\bar{x}_{I E A, \text { Country }_{n}}^{\widetilde{k}}$ by the mean of the adjustment survey $\bar{x}_{\tilde{i}, \text { doubloons }_{n}}^{\tilde{k}}$. 


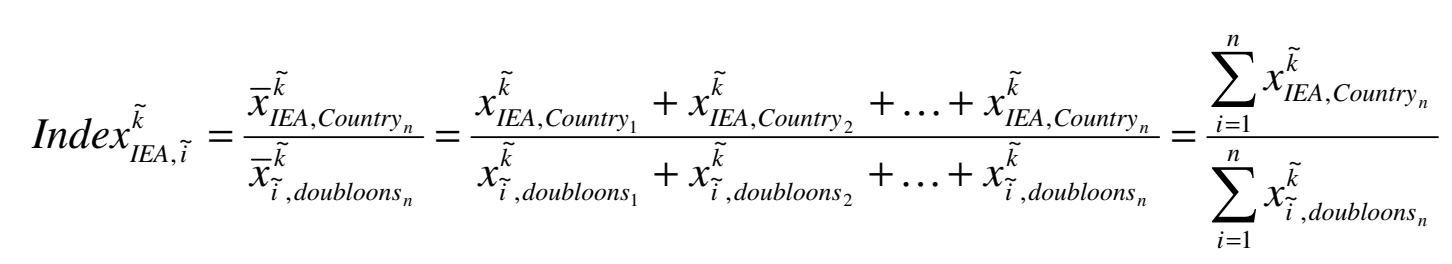

Finally, we proceeded to the calculation of the values of the initial survey, now re-adjusted according to the reference survey. This was done by multiplying the initial result of country $j$ in survey $i$ for subject $k: x_{\tilde{i} j}^{\tilde{k}}$ by the corresponding reference index, namely Index $x_{I E A, \tilde{i}}^{\tilde{k}}$.

$\hat{x}_{\tilde{i} j}^{\tilde{k}}=\left(x_{\tilde{i} j}^{\tilde{k}}\right)_{\text {adjusted }} \times \operatorname{Index} x_{I E A, \tilde{i}}^{\tilde{k}}$

As a result of these procedures, we were able to obtain all the re-adjusted results in mathematics referenced to the TIMSS survey. Moreover, for each country which provided adjusted results in several surveys, the mean of those results was calculated (see Equation 6).

$\hat{\bar{x}}_{\tilde{j}}^{\tilde{k}}=\frac{\sum_{i=1}^{n} \hat{x}_{i j}^{\tilde{k}}}{n}$

We followed the same procedure for measurements in science and reading.

A part of the second database was constructed with a slightly different methodology. In order to obtain comparable measurements in skills over time, we adjusted surveys between 1995 and 2005 using the same methodology described above (with the difference that we did not adjust surveys to a 0-100 scale in order to have comparable indicators with surveys before 1995 and we did not calculate means of surveys as in equation 6 in order to distinguish test achievement over time). 
Concerning surveys before 1995, we matched scores from the United States with results from this country on the National Assessment of Educational Progress (NAEP). The NAEP has been the main national testing instrument in the United States since 1969. Note that we included another survey: the International Assessment of Education Progress (IAEP). The IAEP, begun in 1988, was built on statistical techniques and developped in the United States for the National Assessment of Educational Progress. Like Hanushek and Kimko (2000), we supposed that US scores could be an absolute benchmark of performance to which the U.S. scores on international tests can be keyed. Thus, the mean for each international test series is allowed to drift in accordance to U.S. NAEP score drift and the mean U.S. performance on each international comparison. Finally, we collapsed all series, and agregated those concerning approximately the same year for the same subject and school level, and obtained qualitative indicators for human capital for 105 countries between 1964 and 2005. The panel dataset is unbalanced due to the different number of countries which participated in each survey.

\section{Results}

The cross-country database obtained is based on 271 observations $(104,79$ and 88 for mathematics, science and reading respectively). We constructed a general index (QIHCGeneral) which is equal to the arithmetic mean of the three subjects when available. The panel database obtained is based on 793 observations between 1964 and 2005. Data for the cross section database is annexed as an appendix (see Table 3). The panel database and others indicators of education quality between 1960 and 2005 are available on request.

Table 2 highlights traditional indicators of statistical description for the cross country database. The mean analysis shows that the lowest mean is in mathematics $(69 \%$ success rate), whereas a higher mean is observed in science ( $81 \%$ success rate). Reading is ranked at 
an intermediate position ( $72 \%$ success rate). The variation analysis between the subjects seems rather large. Moreover, the lowest scores differ by about $40 \%$ from the success rate in each of the subjects considered.

\section{Acknowledgement}

The authors are grateful to Jean Bourdon (IREDU-CNRS, University of Bourgogne), Katharina Michaelowa (HWWI, University of Hamburg) and the Referee for their valuable advice.

\section{References}

Hanushek, E.A. and D.D. Kimko, 2000, Schooling, Labor-Force Quality, and the Growth of Nations, American Economic Review, 90(5), 1184-1208.

Lee, J.W. and R.J. Barro, 2001, Schooling Quality in a Cross Section of Countries, Economica, 38(272), 465-488. 
Table 1. International surveys on children's learning achivement

\begin{tabular}{|l|l|l|l|l|}
\hline $\begin{array}{l}\text { Survey } \\
\text { Numbe } \\
\mathrm{r}\end{array}$ & Survey & Year & $\begin{array}{l}\text { Number } \\
\text { of } \\
\text { Surveys }\end{array}$ & Subjects \\
\hline 1 & IAEP & 1988,1990 & 6 & Mathematics, Science \\
\hline 2 & IEA-TIMSS & $\begin{array}{l}1964,1970,1982,1984,1995,1 \\
999,2003\end{array}$ & 16 & Mathematics, Science \\
\hline 3 & IEA-PIRLS & $1970,1990,2001$ & 4 & Reading \\
\hline 4 & OECD-PISA & 2000,2003 & 6 & Mathematics, Science, Reading \\
\hline 5 & UNESCO- & 1997 & 2 & Mathematics, Reading \\
\hline 6 & LABORATORIO & & 2 & Mathematics, Reading \\
\hline 7 & UNESEMEN-PASEC & $1995-2006$ & 3 & Mathematics, Reading \\
\hline 8 & UNESCO-MLA & $1992-1997$ & 3 & Mathematics, Science, Reading \\
\hline
\end{tabular}

Abbreviations: IAEP (International Assessment of Educational Progress), IEA (International Association of the Evaluation of Educational Achievement), TIMSS (Third International Mathematics and Science Study), PIRLS (Progress in International Reading Literacy Study), OECD (Organization for Economic Co-operation and Development), PISA (Programme for International Student Assessment), UNESCO (United Nations Educational, Scientific and Cultural Organization), CONFEMEN (Conference of Francophone Education Ministers), PASEC (Programme on Analysis of Education Systems), SACMEQ (Southern and Eastern Africa Consortium for Monitoring Educational Quality), MLA (Monitoring Learning Achievement).

Table 2. General statistical analysis of the subject indicators

\begin{tabular}{|l|c|c|c|c|c|}
\hline Variable & Observations & Mean & $\begin{array}{c}\text { Standard- } \\
\text { deviation }\end{array}$ & Minimum & Maximum \\
\hline QIHC-General & 105 & 72.41 & 17.32 & 23.20 & 97.74 \\
\hline QIHC-Mathematics & 104 & 69.80 & 16.58 & 22.69 & 100 \\
\hline QIHC-Science & 79 & 80.71 & 13.03 & 42.21 & 100 \\
\hline QIHC-Reading & 89 & 72.74 & 20.39 & 23.71 & 100 \\
\hline
\end{tabular}


Table 3. Qualitative Indicators of Human Capital for 105 countries and the most recent year

\begin{tabular}{|c|c|c|c|c|}
\hline Countries & QIHC-M & QIHC-S & QIHC-L & QIHC-G \\
\hline Argentina & 65.63 & & 72.90 & 69.27 \\
\hline Armenia & 79.01 & 79.76 & & 79.39 \\
\hline Australia & 85.98 & 92.40 & 96.69 & 91.69 \\
\hline Austria & 85.46 & 90.39 & 90.42 & 88.76 \\
\hline Bahrain & 66.28 & 75.78 & & 71.03 \\
\hline Belgium (FI) & 89.05 & 90.03 & 93.37 & 90.82 \\
\hline Belgium (FR) & 83.40 & 78.68 & & 81.04 \\
\hline Benin & 36.19 & & 35.91 & 36.05 \\
\hline Bolivia & 59.78 & & 61.23 & 60.51 \\
\hline Botswana & 57.68 & 59.33 & 44.70 & 53.90 \\
\hline Brazil & 62.88 & 69.55 & 73.50 & 68.64 \\
\hline Bulgaria & 78.68 & 82.87 & 93.89 & 85.15 \\
\hline Burkina Faso & 53.15 & & 54.90 & 54.03 \\
\hline Cameroon & 57.65 & & 68.75 & 63.20 \\
\hline Canada & 87.59 & 91.64 & 95.05 & 91.43 \\
\hline Chad & 45.64 & & 44.79 & 45.22 \\
\hline Chile & 64.31 & 71.45 & 75.16 & 70.31 \\
\hline China & 63.27 & & & 63.27 \\
\hline Chinese Tapei & 96.69 & 98.79 & & 97.74 \\
\hline Colombia & 62.00 & 68.66 & 70.84 & 67.17 \\
\hline Cote d'Ivoire & 46.70 & & 62.39 & 54.55 \\
\hline Cuba & 86.13 & & 91.71 & 88.92 \\
\hline Cyprus & 75.87 & 76.30 & 84.33 & 78.83 \\
\hline Czech Republic & 87.25 & 94.05 & 90.86 & 90.72 \\
\hline Denmark & 83.20 & 82.28 & 90.61 & 85.36 \\
\hline Dominican Rep. & 57.09 & & 60.97 & 59.03 \\
\hline Egypt, Arab Rep. & 67.11 & 72.84 & & 69.98 \\
\hline England & 82.31 & & 94.41 & 88.36 \\
\hline Estonia & 87.77 & 95.50 & & 91.64 \\
\hline Finland & 88.58 & 95.40 & 100 & 94.66 \\
\hline France & 85.80 & 87.16 & 90.48 & 87.81 \\
\hline Germany & 82.83 & 89.12 & 91.22 & 87.72 \\
\hline Ghana & 45.62 & 44.12 & & 44.87 \\
\hline Greece & 75.95 & 84.40 & 88.19 & 82.85 \\
\hline Honduras & 56.36 & & 62.54 & 59.45 \\
\hline Hong-Kong China & 94.87 & 96.16 & 92.03 & 94.35 \\
\hline Hungary & 85.10 & 91.83 & 90.73 & 89.22 \\
\hline Iceland & 82.10 & 85.40 & 89.01 & 85.50 \\
\hline Indonesia & 64.37 & 71.56 & 70.35 & 68.76 \\
\hline Iran, Islamic Rep. & 67.93 & 78.37 & 70.68 & 72.33 \\
\hline Ireland & 84.26 & 89.97 & 94.84 & 89.69 \\
\hline Israel & 81.98 & 84.43 & 86.89 & 84.43 \\
\hline Italy & 79.35 & 85.81 & 90.01 & 85.06 \\
\hline Japan & 92.20 & 96.62 & 91.71 & 93.51 \\
\hline Jordan & 52.42 & 82.18 & & 67.30 \\
\hline
\end{tabular}




\begin{tabular}{|c|c|c|c|c|}
\hline Kenya & 58.70 & & 49.27 & 53.99 \\
\hline Korea, Rep. & 94.45 & 96.24 & 98.34 & 96.34 \\
\hline Kuwait & 62.15 & & 67.60 & 64.88 \\
\hline Latvia & 82.77 & 87.90 & 91.73 & 87.47 \\
\hline Lebanon & 71.57 & 67.99 & & 69.78 \\
\hline Lesotho & 46.61 & & 40.68 & 43.65 \\
\hline Liechenstein & 90.52 & 93.63 & 96.69 & 93.61 \\
\hline Lithuania & 82.98 & 89.79 & 92.70 & 88.49 \\
\hline Luxembourg & 83.26 & 86.14 & 88.21 & 85.87 \\
\hline Macao China & 89.00 & 93.63 & 91.71 & 91.45 \\
\hline Macedonia, FYR & 71.90 & 77.68 & 75.46 & 75.01 \\
\hline Madagascar & 58.93 & 86.11 & 50.56 & 65.20 \\
\hline Malawi & 47.47 & 79.31 & 34.80 & 53.86 \\
\hline Malaysia & 83.97 & 88.24 & & 86.11 \\
\hline Mali & 44.98 & 62.99 & 43.79 & 50.59 \\
\hline Mauritania & 22.69 & & 23.71 & 23.20 \\
\hline Mauritius & 64.36 & 62.31 & 51.14 & 59.27 \\
\hline Mexico & 63.74 & 72.23 & 69.94 & 68.64 \\
\hline Moldova & 76.03 & 81.66 & 83.99 & 80.56 \\
\hline Morocco & 64.66 & 66.43 & 59.75 & 63.61 \\
\hline Mozambique & 55.23 & & 46.58 & 50.91 \\
\hline Namibia & 44.91 & & 40.46 & 42.69 \\
\hline Netherlands & 89.73 & 93.09 & 94.53 & 92.45 \\
\hline New Zealand & 84.99 & 91.44 & 93.22 & 89.88 \\
\hline Niger & 39.66 & 54.95 & 35.99 & 43.53 \\
\hline Norway & 79.90 & 85.89 & 88.63 & 84.81 \\
\hline Oman & 56.78 & 55.52 & & 56.15 \\
\hline Palestinian N.A. & 64.46 & 75.26 & & 69.86 \\
\hline Paraguay & 60.51 & & 65.96 & 63.24 \\
\hline Philippines & 62.48 & 65.22 & & 63.85 \\
\hline Poland & 82.76 & 88.82 & 91.53 & 87.70 \\
\hline Portugal & 75.34 & 81.82 & 88.03 & 81.73 \\
\hline Romania & 78.51 & 81.31 & 87.41 & 82.41 \\
\hline Russian Fed. & 81.50 & 88.07 & 85.77 & 85.11 \\
\hline Saudi Arabia & 54.88 & 68.86 & & 61.87 \\
\hline Scotland & 82.31 & 88.58 & 90.14 & 87.01 \\
\hline Senegal & 22.76 & 46.00 & 43.34 & 37.37 \\
\hline Serbia & 76.32 & 79.36 & 75.87 & 77.18 \\
\hline Seychelles & 57.77 & & 52.47 & 55.12 \\
\hline Singapore & 100 & 100 & 90.14 & 96.71 \\
\hline Slovak Republic & 84.04 & 88.86 & 87.40 & 86.77 \\
\hline Slovenia & 81.49 & 89.97 & 85.70 & 85.72 \\
\hline South Africa & 47.16 & 42.21 & 44.47 & 44.61 \\
\hline Spain & 79.56 & 86.61 & 88.58 & 84.92 \\
\hline Swaziland & 53.83 & & 47.74 & 50.79 \\
\hline Sweden & 84.22 & 90.45 & 95.22 & 89.96 \\
\hline Switzerland & 87.71 & 89.35 & 91.90 & 89.65 \\
\hline Tanzania & 54.44 & & 49.21 & 51.83 \\
\hline Tanzania Zanzibar & 49.83 & & 43.11 & 46.47 \\
\hline
\end{tabular}




\begin{tabular}{|l|c|c|c|c|}
\hline Thailand & 75.05 & 81.14 & 77.35 & 77.85 \\
\hline Togo & 50.04 & & 54.40 & 52.22 \\
\hline Tunisia & 66.13 & 73.42 & 68.96 & 69.50 \\
\hline Turkey & 70.90 & 76.37 & 78.93 & 75.40 \\
\hline Uganda & 54.95 & 72.51 & 47.69 & 58.38 \\
\hline United Kingdom & 82.31 & 94.12 & & 88.22 \\
\hline United Sates & 82.44 & 89.37 & 91.84 & 87.88 \\
\hline Uruguay & 71.27 & 78.12 & 79.93 & 76.44 \\
\hline Venezuela, RB & 55.14 & & 65.43 & 60.29 \\
\hline Zambia & 43.54 & 54.38 & 38.84 & 45.59 \\
\hline Zimbabwe & & & 45.50 & 45.50 \\
\hline
\end{tabular}

Note : QIHC-M "Qualitative Indicators of Human Capital in Mathematics", QIHC-S "Qualitative Indicators of Human Capital in Science", QIHC-R "Qualitative Indicators of Human Capital in Reading", QIHC-G "General Index of Qualitative Indicators of Human Capital". 